\title{
Women's Rights and Gender Equality in Europe and Asia
}

\author{
Sara De Vido
}

\section{Introduction}

Women's rights do not only constitute a fertile ground of research for feminists worldwide, but should be put at the forefront of the research of international law scholars to challenge a male-centred conception of the law. ${ }^{1}$ The international law of human rights is not devoid of guarantees to women: international conventions have been adopted both at the international and regional level, and soft law has spurred the recognition of women's rights over the 20th Century and at the beginning of the 21 st Century. The principle of non-discrimination on the basis of sex is enshrined in the majority of national constitutions, although it is absent from the constitutions of some ASEAN countries, ${ }^{2}$ and States have adopted laws promoting equality between women and men in employment and in many other sectors. Nonetheless, the data available at the international level show that, despite important achievements to combat de jure or formal discrimination, which is nonetheless present, de facto or substantive discrimination is still a matter of severe concern.

\footnotetext{
${ }^{1}$ See in that respect Chinkin and Charlesworth (2000).

${ }^{2}$ The principle of non-discrimination is not included in the constitutions of Brunei Darussalam, Lao PDR, Philippines, and Thailand. Furthermore, Singapore and Indonesia, despite having a provision on non-discrimination, does not mention gender as ground of discrimination.
}

\author{
S. De Vido $(\square)$ \\ Ca' Foscari University, Venice, Italy \\ e-mail: sara.devido@unive.it \\ S. De Vido \\ Manchester International Law Centre Affiliate, Manchester, UK \\ S. De Vido \\ Visiting Academic Hitotsubashi University, Tokyo, Japan \\ (C) The Author(s) 2018 \\ Y. Nakanishi (ed.), Contemporary Issues in Human Rights Law, \\ https://doi.org/10.1007/978-981-10-6129-5_8
}




\subsection{Some Data on Gender (in)Equality}

According to the data provided by the World Bank, the rate of participation of women in paid work in East Asia and the Pacific is $61 \%$, compared to $79 \%$ for men. ${ }^{3}$ Europe and Central Asia present lower rates, due to the persistence of the economic crisis: $51 \%$ for women, $67 \%$ for men. If we have a closer look at two countries belonging to these two areas of the world, Japan and Italy, we can easily see that, despite existing a difference in numerical terms, the gap between female and male population in the labour market is similar. Hence, the rate of the female labour force participation amounts to $49 \%$ in Japan, whereas male labour force participation reaches $70 \%$. In Italy, the percentages are respectively 40 and 60 . The gap is 21 percentage points for Japan, 20 percentage points for Italy.

According to the most recent data available at the European Union level, the gender pay gap is $16 \%$, and this happens despite the fact that women have outnumbered men among new graduates, which implies that female employees are now generally more educated than male employees. ${ }^{4}$ In OECD countries, the gender wage gap, related to full-time employees, has reached, according to the latest data, 15.46\%, with the highest level in Korea (36.60), Estonia (31.50), Japan (26.59), Israel (21.83). ${ }^{5}$ Above the OECD average are also some European countries, such as the Netherlands (20.46), and, shifting to the American continent, the United States (17.91). The lowest rate has been registered in New Zealand (5.62).

As far as violence against women (VAW) is concerned, global statistics published by the World Health Organisation indicate that about 1 in 3 women worldwide have experienced either intimate physical and/or sexual partner violence or non-partner sexual violence in their lifetime, and that most of the violence is intimate partner violence. ${ }^{6}$ Having a look at the different regions of the world, the rate does not significantly differ between Europe (25.4) and Western Pacific area (24.6), although a higher level of violence has been registered in the South-East Asia region (37.7). Furthermore, the data are only partially reliable since women's perception of violence is different and so is the level of reporting to the authorities

\footnotetext{
${ }^{3}$ Gender data portal of the World Bank, available at http://datatopics.worldbank.org/gender/ (last accessed on 1 June 2017). It is a comprehensive source for the latest sex-disaggregated data and gender statistics covering demography, education, health, access to economic opportunities, public life and decision-making, and agency.

${ }^{4}$ European Commission, Report on Equality between women and men 2015, Bruxelles, 2016.

5 https://www.oecd.org/gender/data/genderwagegap.htm (last accessed on 1 June 2017).

${ }^{6} \mathrm{WHO}$, Violence against Women, Intimate Partner and Sexual Violence against Women, updated November 2016.
} 
in cases of abuse. Four of the ten ASEAN countries do not criminalise marital rape, ${ }^{7}$ whereas Japan still has weak legislation on rape. ${ }^{8}$

Against this backdrop, it is clear that discrimination against women, especially in the economic sector and in the case of violence against women, is still persistent, in every country in the world, and if we investigate further, we would easily understand that discrimination is present in multiple sectors, including the health one. Two major discrepancies between Asia (ASEAN countries) and Europe can be caught from the analysis. The first is related to the fact that de jure discrimination is still present in countries such as Brunei Darussalam and Malaysia, where married women cannot either choose where to live or transmit citizenship to their children. ${ }^{9}$ The second discrepancy relates to participation in politics; in Europe, the participation of women is improving. Hence, for example, in Italy, the number of women sitting in the national parliament and in the government are steadily increasing, reaching $30-50 \%$ in $2015 .{ }^{10}$ Broadening the focus, the United States and Canada still present a low percentage of female participation in politics, between 10 and $30 \%$, whereas in Asian countries like Japan and Thailand, the rate is less than $10 \% .{ }^{11}$

\subsection{Purpose and Limits of the Analysis}

The purpose of this chapter is to provide an overview of the evolution of the protection of women's rights in Europe and Asia. The chapter will focus on violence against women and on trafficking of women, on which two recent conventions, respectively in the European and Asian systems, have been adopted. We are referring to the Council of Europe Istanbul Convention on preventing and combating violence against women and domestic violence, concluded in 2011 and entered into force in 2014 (Istanbul Convention), ${ }^{12}$ and to the ASEAN Convention against trafficking in persons, especially women and children (ASEAN Convention against trafficking), opened to signature in 2015 and only recently entered into force. ${ }^{13}$ We will demonstrate that, both in Europe and Asia, significant improvements in the recognition of women's rights and in the promotion of gender equality

\footnotetext{
${ }^{7}$ Data from the ASEAN Action plan on the Elimination of Violence against Women (ASEAN RPA on EVAW), adopted at the summit of November 2015. http://www.asean.org/storage/images/ 2015/November/27th-summit/ASCC_documents/ASEAN\%20Regional\%20Plan\%20of\% 20Action\%20on\%20Elimintation\%20of\%20Violence\%20Against\%20WomenAdopted.pdf (last accessed on 1 June 2017).

${ }^{8}$ Yano (2007, p. 198 ff).

${ }^{9}$ Women, Business and Law data, World Bank, 2016, p. 8.

${ }^{10} \mathrm{http}: / /$ datatopics.worldbank.org/gender/country/italy (last accessed on 1 June 2017).

${ }^{11} \mathrm{http}: / /$ datatopics.worldbank.org/gender (last accessed on 1 June 2017).

${ }^{12}$ CETS No. 210. Number of ratifications as of 1 August 2017: 24.

${ }^{13}$ It entered into force on 8 March 2017, after the deposit by the Philippines of the sixth instrument of ratifications (Article 29 of the Convention).
} 
have been registered, although these measures have not been sufficient to guarantee substantial equality, which goes beyond the mere recognition of the principle of non-discrimination against women, and have not eradicated violence against women. The chapter does not purport to compare two systems which present specific characteristics, but rather to show how the protection of human rights, and in particular women's rights, can benefit from a dialogue between regional experiences. We will therefore support the trend toward 'regionalisation' in the protection of women's rights, encouraging, at the same time, a dialogue between the systems themselves. Despite differences in societies and cultures, discrimination against women does present a common trend, and, in order to eradicate it, States must undertake specific actions of prevention, protection, and, where relevant, prosecution. We will suggest that the Council of Europe Istanbul Convention should constitute a model for further regional legal instruments on the issue, and that non-Member States of the Council of Europe be encouraged by international bodies, such as the UN Special Rapporteur on violence against women, to ratify it. ${ }^{14}$ With regard to ASEAN, we will assess the important step undertaken by member States with the adoption of the ASEAN Convention against trafficking. Nonetheless, we will stress one limit, namely the fact that the text reproduces the provisions enshrined in the 2000 Protocol to prevent, suppress and punish trafficking in persons especially women and children, supplementing the United Nations Convention against transnational organized crime, ${ }^{15}$ without taking into account the peculiarities of the phenomenon in ASEAN countries. ${ }^{16}$

The boundaries of our research should be clearly declared at the outset. The first boundary is geographical. We will focus on the Council of Europe and the European Union, on the one hand, and on ASEAN countries plus Japan, on the other hand. It means that other regions of the world, including Southern Asia, will be excluded from the analysis. The second boundary is 'gendered'. We will only refer to the situation of women, although being perfectly aware of the fact that gender discrimination also concerns LGBTQAI.

\section{Evolution of Women's Rights at the International Level}

In this part we will provide an overview of the main legal instruments in force at the international level for the protection of women's rights before analysing regional instruments in that respect.

As stressed by Charlesworth, 'the major focus of the protection of women's rights internationally has been the right to equal treatment and non-discrimination on the basis of sex. ${ }^{17}$ The equality between the sexes was encapsulated into the UN

\footnotetext{
${ }^{14}$ The Convention is open to non-Member States of the Council of Europe according to Article 76.

${ }^{15}$ The protocol was adopted and opened to signature in 2000.

${ }^{16}$ Asis (2008, p. 190).

${ }^{17}$ Charlesworth (2009, p. 384).
} 
Charter of $1945,{ }^{18}$ although the issue of the status of women had already been placed on the League of Nations agenda in 1935. As it is known, the Universal Declaration of human rights prohibits discrimination on the basis of sex with regard to the enjoyment of the rights enshrined in the Declaration. ${ }^{19}$ The prohibition of discrimination on the basis of sex is also part of the two Covenants on civil and political rights, and on economic, social and cultural rights, respectively at Articles 2(1) and 3, and Articles 2(2) and 3. Since the Covenants do not contain a definition of 'discrimination' or 'equality', and despite the use of the term 'enjoyment' which suggests equality in the outcome, 'many State parties interpreted their obligations narrowly, as requiring formal, rather than substantive, equality.'20

Thirteen years later, the UN General Assembly adopted the Convention on the elimination of all forms of discrimination against women (CEDAW), which is considered as the most significant international legal instrument for the protection of women's rights. The legal instrument points out the specificity of women's experience of discrimination, it provides a definition of 'discrimination against women', ${ }^{21}$ and promotes substantive equality. ${ }^{22}$ It has been ratified by 189 States, including all the member States of the Council of Europe, all ASEAN countries, and Japan. ${ }^{23}$ States parties are obliged to implement the provisions of the Convention, also through a modification of their domestic legislation, and to present periodic reports to the Committee established by the Convention itself (so-called 'CEDAW Committee'). A comparable number of ratifications has not been achieved by the optional protocol to the CEDAW, which was adopted in 1999, and only counts 109 parties. The protocol empowers the Committee to receive complaints lodged by individuals against States which have ratified the protocol itself for violations of the CEDAW. Widely accepted by European countries, the protocol was only ratified by Cambodia, Philippines and Thailand (ASEAN countries), and it has not yet been ratified by Japan. ${ }^{24}$

Even though the importance of the CEDAW cannot be denied, it is necessary to stress that women's participation at UN level is still insufficient, in particular as far as the composition of the UN treaty bodies is concerned. The Committee on economic social and cultural rights is composed, as of 20 February 2017, of only 5 women out of a total of 18 experts, and only recently the situation has improved in

\footnotetext{
${ }^{18}$ Article 1 (4).

${ }^{19}$ Article 2.

${ }^{20}$ Otto (2013, p. 320).

${ }^{21}$ Article 1: 'For the purposes of the present Convention, the term 'discrimination against women' shall mean any distinction, exclusion or restriction made on the basis of sex which has the effect or purpose of impairing or nullifying the recognition, enjoyment or exercise by women, irrespective of their marital status, on a basis of equality of men and women, of human rights and fundamental freedoms in the political, economic, social, cultural, civil or any other field.'

${ }^{22}$ Otto (2013, p. 323).

${ }^{23}$ Consider, however, the reservations appended by some countries.

${ }^{24}$ According to Nakashima (2007, p. 45), the primary reason seems to be that 'Japan considers itself to already have an adequate human rights protection system in place.'
} 
the Human Rights Committee, which counts 8 women out of a total of 18 members. As one can easily imagine, in the CEDAW Committee women are widely represented. Chinkin clearly posits that 'the invisibility of women in the national public sphere has been replicated at the international level with very low participation by women in senior positions in international institutions. 25

Shifting the focus from the international to the regional level, it should be stressed a trend towards the 'regionalisation' of the protection of women's rights, which responds to the challenges stemming from the peculiarities of the society in which these rights are implemented. Therefore, the Council of Europe Istanbul Convention takes into account, for example, the increasing phenomenon of multiculturalism of European societies by prohibiting any kind of justification for crimes based on honour, culture and religion, which implies, among others, a complete ban of female genital mutilation. ${ }^{26}$ The Maputo Protocol to the African Charter on human and peoples' rights on the rights of women in Africa of 2003 stresses the importance of economic, social, cultural and third-generation women's rights, which are not included in the European instrument. Multiculturalism, in the way it has developed in Western countries, differs from the notion of multicultural 'conviviality' as elaborated by some scholars in Japan, a concept which expresses the diversity 'in terms of gender, race, ethnicity, religion, and culture,' that are 'important to contemporary modes of identity and belonging. 27

With regard to women's rights, regionalisation can also be considered a way to encounter the accusation of 'imperialism' exercised by women from the North with regard to women from the South. ${ }^{28}$

\subsection{On the Principle of Non-discrimination}

Compared to other situations, discrimination on the grounds of sex and genderand sexual orientation ${ }^{29}$ - has only recently become high priority at the international level. As posited by Nussbaum, 'brutal and oppressive discrimination on grounds of race is taken to be unacceptable in the global community; but brutal and oppressive discrimination on grounds of sex is often taken to be a legitimate expression of cultural differences. ${ }^{30}$ Furthermore, with regard to women, many violations of women's rights tend to be culturally justified, invoking, in other

\footnotetext{
${ }^{25}$ Chinkin (2012a, p. 1).

${ }^{26}$ Article 38 of the Convention.

${ }^{27}$ According to Ito Ruri (reported in Tsujimura 2010, pp. 4-5), in North America, multiculturalism developed into a comprehensive human rights policy that 'not only includes ethnicity but also gender, sexual orientation, and differences based on disabilities.'

${ }^{28}$ Orford (2002, p. 285), Bond (2003, p. 72).

${ }^{29}$ See Article 21 of the Charter of Fundamental Rights of the European Union (2000/C 364/01), which provides for the first time the case of discrimination on the ground of sexual orientation.

${ }^{30}$ Nussbaum (2006, p. 260).
} 
words, cultural reasons. As Charlesworth points out 'it is striking that 'culture' is much more frequently invoked in the context of women's rights than in any other area,' and this is caused by the fact that 'dominant cultures tends to be conservative and few encourage the participation of women. ${ }^{31}$

Going back to the CEDAW, even though it plays a pivotal role in the protection of women's rights at the international level, it presents some limitations due to an understanding of the principle of non-discrimination which is still biased with regard to women. Dianne Otto argues that CEDAW is based on a continuous comparison with men, which means that women are only entitled of 'special measures' as a vulnerable category, and does not include violence against women as a form of discrimination on the grounds of gender. ${ }^{32}$

\section{Evolution of Women's Rights and Gender Equality in Europe and Asia}

\subsection{The European Union}

The principle of equal pay for equal work was first included in the Treaty of Rome. Article 157 of the Treaty on the functioning of the European Union (TFEU, former Article 119 (1) ECC and Article 141 EC) reads: 'Each Member State shall ensure that the principle of equal pay for male and female workers for equal work or work of equal value is applied.' The principle of equal pay for equal work was extensively interpreted by the European Court of Justice and considered in both its economic and social dimension as "part of the foundations of the Community.,"33 Furthermore, Article 153 TFEU (former 137 EC) empowers the EU to 'support and complement' the activities of the Member States in the field of 'equality between men and women with regard to labour market opportunities and treatment at work.' Gender mainstreaming emerges from Article 8 TFEU, under which in all its activities, the Union shall aim to eliminate inequalities, and to promote equality, between men and women.' According to Article 19 TFEU, the Council, 'acting unanimously in accordance with a special legislative procedure and after obtaining the consent of the European Parliament, may take appropriate action to combat discrimination based on sex, racial or ethnic origin, religion or belief, disability, age or sexual orientation.' European Union law aimed at fighting against human

\footnotetext{
${ }^{31}$ Charlesworth (2009, p. 390).

${ }^{32}$ The recognition of violence against women as a form of discrimination was only achieved in 1992 with General Recommendation no. 19 issued by the CEDAW Committee, and with the subsequent resolution of the UN General Assembly on violence against women of 1993.

${ }^{33}$ Gabrielle Defrenne v. SA Sabena, Case 43/75, judgment of 8 April 1976, European Court of Justice, para. 12. The word 'pay' was also extensively interpreted in order to encompass contracted-out pension schemes (Barber v. Guardian Royal Exchange Assurance group, C-262/88, judgment of 17 may 1990).
} 
trafficking, in particular women and children, has as legal bases Articles 79 and 83 TFEU, the latter aimed at the adoption of minimum rules concerning the definition of criminal offences and sanctions in 'the areas of particularly serious crime with a cross-border dimension.'

The Lisbon treaty has qualified equality between women and men as one of the five founding values of the European Union (Article 2 of the Treaty on European Union, TEU). Equality is also among the aims of the EU (Article 3 (3) TEU), on which the organisation 'shall develop a special relationship with neighbouring countries' (Article 8 TEU). Since the Lisbon treaty, the Charter of fundamental rights of the EU has the same legal value as the treaties (Article 6 TEU), and contains an entire chapter (III) on equality. According to its Article 23: 'Equality between men and women must be ensured in all areas, including employment, work and pay. The principle of equality shall not prevent the maintenance or adoption of measures providing for specific advantages in favour of the under-represented sex.'

The protection of women from gender-based violence is neither enshrined in the EU treaties nor in the Charter of Fundamental Rights, a fact that has not prevented the EU from taking action to counteract the offences related to violence against women. The action of the EU has been mainly devoted to the achievement of gender equality, which also encompasses initiatives with regard to the eradication of violence against women. ${ }^{34}$ The only reference to violence against women in the EU Treaties can be found in Declaration 19 to the Final Act of the 2007, referring to Article 8 TFEU, which provides that among the efforts to 'eliminate inequalities between women and men,' the Union will aim to combat all kinds of domestic violence in its different policies. ${ }^{35}$

As far as secondary legislation is concerned, several acts have been adopted over the years with regard to equality in employment, starting from Directive 75/117/EEC of 10 February 1975 on the approximation of the laws of the Member States relating to the application of the principle of equal pay for men and women. ${ }^{36}$ With regard to violence against women, the EU has adopted specific measures aimed at countering the trafficking of human beings, in particular women and children, ${ }^{37}$ and the victims of crime, including Regulation (EU) 606/2013 on the mutual recognition of protection measures in civil matters which will play a pivotal role in the recognition of restriction orders; and Directive 2012/29/EU, establishing

\footnotetext{
${ }^{34}$ See Hervey (2005, p. 307 ff.); and Sümer (2009, p. 67).

${ }^{35}$ Declaration on Article 8 of the Treaty on the Functioning of the European Union, annexed to the Final Act of the Intergovernmental Conference which adopted the Treaty of Lisbon, signed on 13 December 2007.

${ }^{36}$ Directive 75/117/EEC on the approximation of the laws of the Member States relating to the application of the principle of equal pay for men and women [1975] L45/19.

${ }^{37}$ Directive 2011/36/EU on preventing and combating trafficking in human beings and protecting its victims, and replacing Council Framework Decision 2002/629/JHA [2011] L101/1. For the purpose of our analysis, we have decided to focus on the Council of Europe Istanbul Convention.
} 
minimum standards on the rights, support and protection of victims of crime. ${ }^{38}$ The EU addressed the offence of sexual harassment committed in the workplace in Council Directive 2000/78/EC, established a general framework for equal treatment in employment and occupation in Directive 2002/73/EC, and created Directive 2006/54/EC on the implementation of the principle of equal opportunities and equal treatment of men and women in matters of employment and occupation address harassment, including sexual harassment. ${ }^{39}$

Moving from legal instruments to policies and non-binding acts, it should be acknowledged that the EU has been prolific in the adoption of measures to address different aspects of gender inequality. The European Parliament has been active in combating violence against women and domestic violence since as early as 1979 , when it voted in favour of establishing the ad hoc Committee on women's rights. ${ }^{40}$ The EU Parliament Committee on Women's Rights and Gender Equality continues its activity in present day, dealing with several issues, including the eradication of violence against women. Furthermore, in 2006, the EU established the European Institute for Gender Equality (EIGE) in Regulation (EC) No. 1922/2006, which launched the Gender Equality Index in 2015. ${ }^{41}$ The European Commission, along with the support given to numerous awareness-raising campaigns in EU countries, adopted the Women's Charter in $2010,{ }^{42}$ and in June 2015 promoted a 'Forum on the Future of Gender Equality in the European Union. ${ }^{43}$ With specific regard to

\footnotetext{
${ }^{38}$ Regulation (EU) 606/2013 on mutual recognition of protection measures in civil matters [2013] L 181/4. See also Directive 2012/29/EU establishing minimum standards on the rights, support and protection of victims of crime, and replacing Council Framework Decision 2001/220/JHA [2012] L 315/57; Directive 2011/99/EU on the European protection order [2011] L 338/2.

${ }^{39}$ Directive 2000/78/EC establishing a general framework for equal treatment in employment and occupation [2000] L 303/16; Directive 2002/73/EC on the implementation of the principle of equal treatment for men and women as regards access to employment, vocational training and promotion, and working conditions [2000] L 269/15; Directive 2006/54/EC on the implementation of the principle of equal opportunities and equal treatment of men and women in matters of employment and occupation (recast) [2006] L 204/23. See also the European Added Value Assessment Combatting violence against women, 'An assessment accompanying the European Parliament's Legislative own-Initiative Report (Rapporteur Antonyia Parvanova, MEP)' (2013) 15 http://www. europarl.europa.eu/meetdocs/2009_2014/documents/femm/dv/eav_violence-against-women-/eav_ violence-against-women-en.pdf (last accessed on 1 June 2017).

${ }^{40}$ It should be noted that Simone Veil was at that time the president of the European Parliament and the first woman to be elected for this position.

${ }^{41}$ The progress in gender equality are still not sufficient. See http://eige.europa.eu/news-andevents/news/eige-launches-gender-equality-index-2015-marginal-improvements-gender-equality (last accessed on 1 June 2017).

${ }^{42}$ Communication from the Commission, A Strengthened Commitment to Equality between Women and Men-A Women's Charter: Declaration by the European Commission on the occasion of the 2010 International Women's Day in commemoration of the 15th anniversary of the adoption of a Declaration and Platform for Action at the Beijing UN World Conference on Women and of the 30th anniversary of the UN Convention on the Elimination of All Forms of Discrimination against Women COM (2010) 78 final.

${ }^{43}$ See the Report of 10 June 2015 http://ec.europa.eu/justice/events/future-of-gender-equality2015/files/report_forum_gender_equality_en.pdf (last accessed on 1 June 2017).
} 
one form of violence against women - female genital mutilation - all EU institutions have clearly taken a position to prohibit the practice. ${ }^{44}$ In the conclusions presented by the EU General Affairs Council in 2013, 'An overarching post-2015 framework', the institution particularly stressed the importance of the principle of equality, by acknowledging that the empowerment of women and girls, and the prevention of violence against women, are 'preconditions' for achieving equitable and inclusive sustainable development. ${ }^{45}$

EU measures for the promotion of women's rights are undoubtedly advanced although they have not been enough to reach de facto equality for women in the 27 (after Brexit is completed) Member States. EU directives need implementation at domestic level. Furthermore, the legal framework is fragmented in a panoply of acts which lack unity. Concerning the action to combat violence against women, this unity could be achieved thanks to the ratification by the EU of the Council of Europe Istanbul Convention. ${ }^{46}$

\subsection{Council of Europe}

The Council of Europe has promoted de jure and de facto gender equality in its 47 Member States since 1980s. Four binding legal instruments must be mentioned in the field of women's rights. Firstly, the European Convention on human rights, dating back to 1950, contains many provisions that can be applied - and have been by the European Court of human rights in its judgments-in order to protect women's rights. Article 14 provides for the prohibition of discrimination on 'any ground', including sex. The protection of women's rights can be also achieved through the application of the provisions on, among others, the right to life, the right to respect for private and family life, the prohibition of torture, and the prohibition of slavery and forced labour. With regard to the latter, the jurisprudence of the European Court of human rights has played a fundamental role in bringing the prohibition of trafficking within the terms of Article 4 of the European Convention. $^{47}$

\footnotetext{
${ }^{44}$ See, for example, European Parliament Resolution on Ending Female Genital Mutilation (2012/2684(RSP)); EU Commission, Communication to the European Parliament and the Council Towards the elimination of female genital mutilation $\operatorname{COM(2013)~} 833$ final; European Parliament Resolution on the Commission Communication entitled 'Towards the elimination of female genital mutilation' (2014/2511(RSP)); Council of the EU Justice and Home Affairs Conclusions on preventing and combating all forms of violence against women and girls, including female genital mutilation, 5 June 2014.

${ }^{45}$ The Overarching Post 2015 Agenda-Council conclusions, General Affairs Council meeting Luxembourg, 25 June 2013, http://www.consilium.europa.eu/uedocs/cms_data/docs/pressdata/en/ foraff/137606.pdf (last accessed on 1 June 2017).

${ }^{46}$ See, in that respect, De Vido (2017).

${ }^{47}$ Rantsev v. Cyprus and Russia, judgment of 7 January 2010, European Court of Human Rights, paras. $277-278$.
} 
Secondly, following a chronological order, the European Social Charter emphasises the importance of equality in matters of employment and occupation (Article 1).

Thirdly, another fundamental instrument is the Council of Europe Convention on action against human trafficking adopted in 2005 and entered into force in 2008. It builds on the UN Protocol to the Palermo Convention, ${ }^{48}$ but, compared to the former, it focuses more on the protection of the victim rather than on law enforcement provisions, and provides for higher standards of sanctions against traffickers. ${ }^{49}$ The gender-based approach emerges from the very beginning of the text of the Convention. According to Article 1, the main purpose of the legal instrument is to 'prevent and combat trafficking in human beings, while guaranteeing gender equality.' The Convention affirms for the first time that trafficking in human beings constitutes a violation of human rights. ${ }^{50}$ The implementation of the legal instrument is guaranteed by a group of experts, called GRETA, which periodically prepares reports in which it analyses and evaluates the measures adopted by a State party to implement the Convention.

The fourth binding instrument which must be mentioned is the Council of Europe Istanbul Convention on preventing and combating violence against women and domestic violence, adopted in 2011, which will be object of analysis in the following paragraph.

Other non-binding instruments (recommendations, action plans, key standards) have been adopted over the years to promote gender equality. ${ }^{51}$ The Council of

\footnotetext{
${ }^{48}$ See the definition of trafficking at Article 4 (a): 'Trafficking in human beings shall mean the recruitment, transportation, transfer, harbouring or receipt of persons, by means of the threat or use of force or other forms of coercion, of abduction, of fraud, of deception, of the abuse of power or of a position of vulnerability or of the giving or receiving of payments or benefits to achieve the consent of a person having control over another person, for the purpose of exploitation. Exploitation shall include, at a minimum, the exploitation of the prostitution of others or other forms of sexual exploitation, forced labour or services, slavery or practices similar to slavery, servitude or the removal of organs.'

${ }^{49}$ See Gallagher and Holmes (2008, p. 322), Pati (2009, p. 335).

${ }^{50}$ The UN Protocol only refers in the preamble to the protection of the victims' internationally recognized human rights.

${ }^{51}$ Council of Europe Key Standards on Gender Equality and Women's Rights (2015); Make equality in law a reality in fact - Compilation of recommendations of the Committee of Ministers in the field of equality between women and men (2011); Recommendation $\operatorname{Rec}(2007) 17$ of the Committee of Ministers to member states on gender equality standards and mechanisms adopted on 21 November 2007 and explanatory memorandum; EG (2009) 2 Report: National machinery, action plans and gender mainstreaming in the Council of Europe member states since the 4th World Conference on Women (Beijing 1995); Stocktaking study of the effective functioning of national mechanisms for gender equality in Council of Europe member states; EG (2004) 4 Report: National machinery, action plans and gender mainstreaming in the Council of Europe member states since the 4th World Conference on Women (Beijing 1995); EG (2001) 7 Handbook on national machinery to promote gender equality and action plansGuidelines for establishing and implementing national machinery to promote equality, with examples of good practice; EG-S-PA (2000) 7 Report: Positive Action in the Field of Equality between Women and Men; Recommendation R (85) 2 of the Committee of Ministers on legal protection against sex
} 
Europe also endorsed in November 2013 the Gender Equality Strategy which includes five strategic goals: combating gender stereotypes and sexism; combating violence against women; guaranteeing equal access of women to justice; achieving balanced participation of women and men in political and public decision-making; achieving gender mainstreaming in all policies and measures. ${ }^{52}$ The strategy counts on a Gender Equality Commission, composed of members appointed by the member States; a network of national focal points in each member State; gender equality rapporteurs within the steering committees and other intergovernmental structures of the Council of Europe; and finally an Inter Secretariat gender mainstreaming team. It should be noted that the gender equality commission does not deal with violence against women, which is part of the mandate of GREVIO, the Committee established by the Council of Europe Istanbul Convention.

\subsubsection{The Council of Europe Istanbul Convention}

The Council of Europe Istanbul Convention is the most advanced legal instrument in force at regional level to combat violence against women and domestic violence. ${ }^{53}$ It is not the purpose here to analyse the Convention article by article; the explanatory notes by the Council of Europe are sufficiently clear to understand the scope and the main provisions of the treaty. ${ }^{54} \mathrm{~A}$ few remarks are however necessary in order to appraise the potential added value of the Convention also for Asian countries, which do not belong to the system of the Council of Europe. The Istanbul Convention clearly differentiates between violence against women and domestic violence which might affect women but also children, men, and elderly people. Violence against women is defined as 'a violation of human rights and a form of discrimination against women,' which include 'all acts of gender-based violence that result in, or are likely to result in, physical, sexual, psychological or economic harm or suffering to women, including threats of such acts, coercion or arbitrary deprivation of liberty, whether occurring in public or in private life' (Article 3.a). The definition of domestic violence does not solely refer to acts committed against women, rather to any kind of physical, sexual, psychological or economic violence 'that occur within the family or domestic unit or between former or current spouses or partners, whether or not the perpetrator shares or has shared the same residence with the victim' (Article 3.b). With regard to States' obligations deriving from

\section{(Footnote 51 continued)}

discrimination; Recommendation $\mathrm{CM} / \operatorname{Rec}(2012) 6$ of the Committee of Ministers on the protection and promotion of the rights of women and girls with disabilities.

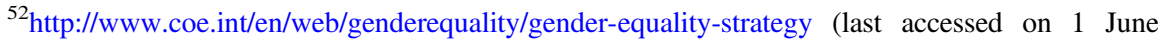
2017).

${ }^{53}$ At regional level, two other instruments must be mentioned: the Belém do Parà Convention (Inter-American system) and the Maputo Protocol (African system).

${ }^{54}$ Explanatory Report to the Council of Europe Convention on preventing and combating violence against women and domestic violence Istanbul, 11 May 2011. 
treaty provisions, the Convention requires State parties to criminalise several forms of conduct which amount to violence against women and domestic violence, whether these forms of conduct have not yet been included in their respective criminal codes. The types of conduct encompass forced marriage, female genital mutilation, forced abortion, stalking, sexual harassment, physical and psychological violence and sexual violence. The Convention also requires State parties to ensure that in criminal proceedings regarding the acts of violence covered by the Convention, 'culture, custom, religion, tradition or so-called 'honour' are not regarded as justifications of such acts' (Article 42, para 1). ${ }^{55}$ The Convention then obliges State parties to take the necessary legislative or other measures to ensure that the offences established in the Convention are punishable by effective, proportionate and dissuasive sanctions (Article 45), taking into account their seriousness and aggravating circumstances, such as the fact that the acts are committed in the presence of a child (Article 46). As for preventive and protective measures, States must promote 'changes in the social and cultural patterns of behavior of women and men with a view to eradicating customs, traditions and all other practices which are based on the idea of the inferiority of women or on stereotyped roles for women and men' (Article 12), ${ }^{56}$ and provide support services for victims of violence, including legal and psychological counselling, financial assistance, housing, education, training and assistance in finding employment (Article 20), specialist support services (Article 22), shelters (Article 23), and telephone helplines (Article 24). In order to implement the obligations set out the Convention, States must allocate 'appropriate measures and human resources,' thus creating a precise legal obligation in terms of public expenditure.

Similar to other Council of Europe conventions, including that against human trafficking, the Convention provides for a monitoring system, called GREVIO, composed of independent experts, whose mandate is to assess State parties compliance with treaty obligations.

Despite being the most advanced instrument in force at the international level on combating violence against women and domestic violence, the Convention is not devoid of criticism: the notion of gender, due to pressures by Russia and the Holy See during negotiations, is limited to the two sexes, male and female. Furthermore, the Convention does not address prostitution as a form of violence; finally, it does not take into account new forms of violence such as the ones committed in the cyber world. ${ }^{57}$

It has however a huge potential: to reach universal application. This situation may occur in two ways: either the UN adopts an international convention with

\footnotetext{
${ }^{55}$ For a more detailed analysis of the Istanbul Convention, let us refer to De Vido (De Vido 2016a, b).

${ }^{56}$ On the concrete actions to be undertaken in order to implement this article, see Marianne Hester, Sarah-Jane Lilley, Preventing Violence against Women: Article 12 of the Istanbul Convention https:// rm.coe.int/CoERMPublicCommonSearchServices/DisplayDCTMContent?documentId= 090000168046e1f0.

${ }^{57}$ See in more detail, De Vido (2016a).
} 
regard to violence against women which draws a lot from the Istanbul Convention, according to a draft published in the 2015 report presented by the UN Special Rapporteur on Violence against Women, ${ }^{58}$ or the Convention is ratified by the EU, on the one hand, and by an increasing number of non-Council of Europe Members, on the other. With regard to Asian countries, the Convention could become a model to negotiate a new regional convention that takes into account the lesson learnt from the evolution of the European legal instrument, including the monitoring mechanism, or be ratified by ASEAN countries and by Japan, the latter having already ratified Council of Europe conventions in its role as Observer State. ${ }^{59}$

\subsection{ASEAN Countries}

In order to implement the 1993 Vienna Declaration and Programme of Action, ASEAN countries decided to establish the ASEAN Intergovernmental Commission on Human Rights (AICHR), whose terms of reference were approved by the ASEAN Foreign Minister Meeting in July 2009. Some years later, in 2012, ASEAN adopted the Charter of human rights, which constitutes the only significant (non-binding) comprehensive instrument in the field of human rights for the ASEAN region. The Charter expressly contains the principle of non-discrimination on the basis of 'gender.' ${ }^{60}$ The system of human rights protection is still recent and it will take time before assessing its effectiveness.

As of 2015, the ten ASEAN countries have entered a regional cooperation called 'ASEAN Economic Community.' This major achievement reminds us of the history of the then European Economic Communities, started as a process of pure economic integration and then evolved to encompass an increasing number of political issues and to develop a system of protection of human rights. Even prior to 2015, though, ASEAN has considered gender mainstreaming in its policies, and all countries have committed to respect women's rights as a consequence of the ratification of the CEDAW. ${ }^{61}$ The Secretary-General of ASEAN, Le Luong Minh, declared in 2013, in his opening remarks at a Gender Mainstreaming Training Session launched by the ASEAN Secretariat, that 'the spirit of promoting gender equality should be an integrated part of ASEAN's policies and programmes towards the ASEAN Community. The goal of gender equality should be central to all three

\footnotetext{
${ }^{58}$ Addendum to the Human Right Council Thematic Report of the Special Rapporteur on Violence against Women, its Causes and Consequences (A/HRC/29/27/Add. 4), 16 June 2015.

${ }^{59} \mathrm{http} / / / \mathrm{www} . c o e . i n t / e n / w e b / c o n v e n t i o n s /$ search-on-states/-/conventions/treaty/country/JAP (last accessed on 1 June 2017).

${ }^{60}$ Article 2.

${ }^{61}$ However, consider the reservations appended by Brunei Darussalam and Malaysia which refer to Islamic sharia. ASEAN established the ASEAN Committee on women as ASEAN sectoral body in 1976.
} 
pillars of economy, political-security and socio-cultural of ASEAN. ${ }^{62}$ The deputy Secretary-General for ASEAN socio-cultural community, Alicia R. Bala, pointed out that 'the role of ASEAN Secretariat is critical in making gender mainstreaming as a standard practice in ASEAN's policies and programmes across the three pillars.' She then added that 'before we are able to effectively stimulate gender mainstreaming strategy in ASEAN, we first need to understand clearly the concept of gender equality and how gender mainstreaming strategy can be applied in our work. ${ }^{63}$

With regard to specific initiatives and legal instruments adopted to promote women's rights, ASEAN established in 2010 the Commission on the promotion and protection of women and children's rights (ACWC). The nature of the Commission is intergovernmental, being composed of two representatives from each ASEAN country. According to its terms of reference, its mandate is to promote 'the implementation of international instruments, ASEAN instruments and other instruments related to the rights of women and children' (para. 5.1), and 'to develop policies, programs and innovative strategies to promote and protect the rights of women and children to complement the building of the ASEAN Community' (para. 5.2). Despite acknowledging the importance of a cooperative approach to enhance women and children's rights, the act recognises 'the primary responsibility to promote and protect the fundamental freedoms and rights of women and children rests with each Member State' (para. 3.5). This clause seems to protect the position of countries, such as Brunei, that allow forms of discrimination against women based either on religion or on culture. The Commission presents an annual report to the ASEAN Ministers meeting on social welfare and development. The Commission has played a central role in promoting effective implementation of common issues in the CEDAW and in the 1989 Convention on the rights of the child, however it presents some weaknesses. The first one concerns its composition: independent experts would better guarantee the promotion of women's rights, since there would be no influence on their activity by national governments. The second limit regards its mandate, which does not include either the elaboration of reports on each ASEAN or the analysis of individual complaints. Effective implementation of international provisions requires the possibility for individuals to obtain compensation for alleged violations of their rights. ${ }^{64}$ Whether the national system is weak in that respect, a regional independent mechanism could help in pursuing the promotion of human rights.

The ACWC drafted the Declaration on the Elimination of Violence against Women and Violence against Children in ASEAN, which was then adopted by the

\footnotetext{
${ }^{62}$ ASEAN SG: Gender Equality should be Central in Achieving ASEAN Community, 13 February 2013. http://asean.org/asean-sg-gender-equality-should-be-central-in-achieving-asean-community/ (last accessed on 1 June 2017).

${ }^{63}$ ASEAN SG (2013).

${ }^{64}$ The UN system of human rights treaty bodies is not perfect, though, and requires some reforms, but it has made important achievements. Stoll (2012, p. 12).
} 
ASEAN Summit on 9 October 2013. ${ }^{65}$ It develops a former Declaration on the Elimination of Violence against Women which was approved in 2004. With the Declaration, clearly non-binding, ASEAN Member States 'express common resolve to eliminate violence against women and violence against children in the region' through different measures, including through amendments to national legislation. It refers to a 'holistic' and multi-disciplinary approach to promote the rights of women and children, stressing the importance of developing plans and programmes, allocating adequate resources and budgeting. In the list of commitments undertaken by ASEAN countries, it is possible to identify the three main pillars, namely Prevention, Protection and Prosecution which are also relevant for the Council of Europe Istanbul Convention, although the text of the ASEAN Declaration is excessively general. We can indeed find a quite general commitment to adopt measures of protection for victims and survivors, measures to ensure investigation, prosecution, punishment, and rehabilitation of perpetrators, and measures of prevention in the promotion of 'family support services, parenting education, education and public awareness on the rights of women and children and the nature and causes of violence against women and violence against children to encourage active public participation in the prevention and elimination of violence' (para. 3). It is interesting that the declaration condemns 'harmful practices which perpetuate gender stereotyping' (para. 3), although no specific commitment for ASEAN countries, such as, for example, the criminalisation of culturally-motivated acts which amount to violence against women, has been envisaged. ${ }^{66}$ Another interesting aspect is the fact that the Declaration invites countries to strengthen the existing national mechanisms in implementing, monitoring and reporting the implementation of the Concluding Observations and Recommendations of CEDAW' and other treaty bodies 'as well as the accepted recommendations under the Universal Periodic Review Process of the United Nations Human Rights Council related to the elimination of all forms of violence against women and violence against children.' This affirmation can be seen as a recognition of the international system of protection of human rights.

The Declaration must be read together with the ASEAN Regional Plan of Action on the Elimination of Violence against Women, adopted in November 2015, which is advanced and more detailed compared to the text of the Declaration. It invokes a human-rights based approach to eliminate VAW so as to empower victims and survivors to access information and remedies; furthermore, it provides for due diligence obligations in preventing and combating VAW. ${ }^{67}$ Although there is no reference to the Council of Europe Istanbul Convention, the structure that the action plan follows is similar: measures are divided into the three pillars of prevention,

\footnotetext{
${ }^{65}$ The text of the Declaration is available at http://www.ohchr.org/Documents/Issues/Women/WG/ ASEANdeclarationVaW_violenceagainstchildren.pdf (last accessed on 1 June 2017).

${ }^{66}$ On gender stereotyping, see the work by Cook and Cusack (2010).

${ }^{67} \mathrm{http} / / /$ www.asean.org/storage/images/2015/November/27th-summit/ASCC_documents/ASEAN \%20Regional\%20Plan\%20of\%20Action\%20on\%20Elimintation\%20of\%20Violence\%20Against $\% 20$ WomenAdopted.pdf (last accessed on 1 June 2017).
} 
protection and prosecution. The action plan also envisages an 'accountability framework' aimed at tracking progress towards time-bound targets related to the situation of VAW in the region. At the end of the text, every country has identified initiatives, gaps and challenges with regard to violence against women and children.

The framework is extremely promising, although the action plan is a non-binding act and the implementation relies on an intergovernmental body.

\subsubsection{The Convention Against Human Trafficking}

The fundamental binding instrument in the field of human rights, and women's rights in particular, in Asian countries is the ASEAN Convention against trafficking in persons, especially women and children, adopted in 2015. Trafficking in persons affects all regions and most countries in the world. As we have anticipated, the Council of Europe adopted, more than ten years ago, a specific convention in the field, which now faces the challenges of recent days, with hundreds of female refugees that are at risk of being trafficked. South-East Asia has always been at the centre of the routes of trafficking. Thailand is both a country of destination of most countries in the sub-region, and a country of origin of women trafficked for prostitution destined to Japan and to Western countries. ${ }^{68}$ Furthermore, trafficked persons in Thailand are mostly women and children from Burma, Cambodia, Laos, and Yunnan. States sometimes contribute to trafficking women, by a process of legalisation of activity of 'entertainment'. Hence, for example, the legal migration of entertainers from the Philippines to Japan and South Korea is an example of involvement of the State in trafficking. ${ }^{69}$

All ASEAN countries except Brunei have ratified the UN Protocol to prevent, suppress and punish trafficking in persons, especially women and children, of 2000. The UN Protocol provided for the first time in history a definition of trafficking. The offence is composed of three cumulative elements: an action, consisting of recruitment, transportation, transfer, harbouring or receipt of persons; the means, which include the threat or use of force or other forms of coercion, abduction, fraud, deception, abuse of power or position of vulnerability, giving or receiving payments or benefits to achieve consent of a person having control over another; a purpose of exploitation, which includes, at the minimum, the exploitation of the prostitution of others, or other forms of sexual exploitation, forced labour or services, slavery or practices similar to slavery, servitude, or the removal of organs. ${ }^{70}$ The UN Protocol is a landmark step forward in combating human trafficking at the international level, although it contains 'very little in the way of hard obligations' with regard to the protection of the victims. ${ }^{71}$

\footnotetext{
${ }^{68}$ Asis (2008, p. 190).

${ }^{69}$ Asis (2008, p. 196).

${ }^{70}$ Gallagher (2001, pp. 986-987); Gallagher (2010, p. 29).

${ }^{71}$ Gallagher (2001, pp. 990-993).
} 
The ASEAN Convention draws a lot on the UN Protocol and the Palermo Convention on transnational organized crime, although in the preamble it reproduces one of the recitals of the Council of Europe Convention of 2005: 'recognizing that trafficking in persons constitutes a violation of human rights and an offence to the dignity of human beings.' The UN Protocol and the ASEAN Convention share the same purposes, namely to prevent and combat trafficking, paying particular attention to women and children; to protect and assist victims; and to promote and facilitate cooperation among States. ${ }^{72}$ They both provide for the criminalisation of trafficking in persons, although it seems that the ASEAN Convention is of wider scope, where it refers to offences that are transnational in nature, 'including those committed by organized criminal groups. ${ }^{73}$ In other words, it seems that offences committed by individuals not belonging to organised criminal groups can be brought within the terms of the ASEAN Convention. Compared to the UN Protocol and the Palermo Convention, the ASEAN Convention contains similar provisions on prevention, protection and law enforcement. An interesting difference is that, whereas the UN Protocol requires States to 'consider implementing measures to provide for the physical, psychological and social recovery of victims' (Article 6), the ASEAN Convention obliges each State party to 'provide care and support to victims' of trafficking in persons [Article 14 (10)]. The ASEAN Senior officials meeting on transnational crime is responsible for monitoring the implementation of the Convention.

The Convention, although it has only recently entered into force, significantly contributes to the enhancement of the legal framework against trafficking in persons in the region. However, it has extensively drawn on the generic provisions of the UN Protocol, without taking into consideration the specific situation of ASEAN countries, where women are also legally trafficked through the migration of entertainers. ${ }^{74}$ Furthermore, it does not consider that violent abuse is not limited to the act of trafficking into sexual servitude. As observed, 'women sold into domestic servitude may be subject to sexual abuse as well,' they 'may be forced to work long hours without breaks,' and 'may be trafficked into marriage with men they do not want to marry. ${ }^{75}$ The lack of reference to State responsibility was stressed, with regard to the UN Protocol, by Anne Gallagher, who argued that international law requires States 'to be held answerable for their acts and omissions that cause or otherwise contribute to trafficking. ${ }^{, 76}$ Mutatis mutandis, we can argue the same with regard to the ASEAN Convention. Furthermore, according to Article 26 of the ASEAN Convention, States can agree to provide assistance to each other according

\footnotetext{
${ }^{72}$ Respectively Article 2 and Article 1.

${ }^{73}$ The UN Protocol applies 'to the prevention, investigation and prosecution of the offences established in accordance with article 5 of this Protocol, where those offences are transnational in nature and involve an organized criminal group, as well as to the protection of victims of such offences.' (Article 4).

${ }^{74}$ Asis (2008, p. 196).

${ }^{75}$ Shelley $(2011$, p. 41$)$.

${ }^{76}$ Gallagher (2010, p. 218).
} 
to other international agreements or the provisions of their respective domestic laws. This might undermine the effectiveness of the Convention. The monitoring mechanism is also not comparable to other mechanisms existing at regional levelwe are referring here in particular to GRETA within the Council of Europe. It seems therefore significant that on 3 October 2016, the ACWC launched the regional review on laws, policies and practices within ASEAN related to the identification, management and treatment of victims of trafficking, especially women and children, to support the implementation of the Convention against trafficking. ${ }^{77}$ This mechanism has huge potential in the future. Hopefully other countries in the region will ratify the Convention, including Japan which is country of destination of trafficked persons and also country of transit to the Americas.

\subsubsection{Japan}

After the Second World War, Japanese women obtained rights equal to men under the Constitution, therefore they were emancipated from legal subordination under the prior patriarchal household (i.e.) system. Japan ratified the CEDAW Convention in 1985, and, as a consequence, significant changes in Japanese law occurred, starting from the amendment to the Law for Equal Employment Opportunity of Men and Women in 1997. In 1999, the Basic Law for a Gender Equal Society contained the clear commitment by the government to realise 'a gender-equal society'. ${ }^{78}$ However, as stressed by Miyoko Tsujimura, 'the reality and praxis of women's lives have not necessarily reflected this,' both in the society and in the legal system. ${ }^{79}$ Furthermore, the gender division of labour is still narrowing women's choices. ${ }^{80}$ In compliance with legal obligations stemming from the CEDAW, Japan has periodically presented reports to the CEDAW Committee, which published in March 2016 its most recent concluding observations. ${ }^{81}$

We will consider the CEDAW report on Japan only with regard to the two aspects which are object of analysis in this chapter, namely violence against women and trafficking in women. ${ }^{82}$ As far as VAW is concerned, in Japanese society domestic violence was identified as a social issue in 1990s. In 2001, Japan adopted the Law for the Prevention of Spousal Violence and the Protection of the Victims, later amended in $2004 .{ }^{83}$ Since it refers to spousal violence, the law does not cover

\footnotetext{
${ }^{77} \mathrm{http}$ ///asean.org/asean-strengthens-efforts-to-eliminate-trafficking-in-persons/ (last accessed on 1 June 2017).

${ }^{78}$ Tsujimura (2007, p. 8). The Basic Law for a Gender-Equal Society, act no. 78 of 23 June 1999. English translation at www.japaneselawtranslation.go.jp/ (last accessed on 1 June 2017).

${ }^{79}$ Tsujimura (2007, p. 7).

${ }^{80}$ Asakura (2005, p. 187).

${ }^{81}$ CEDAW Committee, CEDAW/C/JPN/CO/7-8, 7 March 2016.

${ }^{82}$ On discrimination against women with regard to the remarriage period after divorce and the couple's surname after the marriage, De Vido (2016c).

${ }^{83}$ Act on the Prevention of Spousal Violence and the Protection of Victims, Act No. 31 of 13 April $2001 \mathrm{http}: / / \mathrm{www} . j a p a n e s e l a w t r a n s l a t i o n . g o . j p / l a w / d e t a i l$ main?vm=02\&id=113.
} 
cases where violence is perpetrated by boyfriends and short-term cohabitants. Furthermore, sexual crimes provisions contained in the criminal law have never been updated over the past 100 years, 'which demonstrates a lack of consideration of the relationship between violence against women and sexual crimes. ${ }^{84}$ Rape is criminalised in Article 177 of the Japanese penal code, which reads: '[a] person who, through assault or intimidation, forcibly commits sexual intercourse with a female of not less than thirteen years of age commits the crime of rape and shall be punished by imprisonment with work for a definite term of not less than 3 years. The same shall apply to a person who commits sexual intercourse with a female under thirteen years of age.' The provision is clearly discriminatory against women, and also against men, who might be victims of sexual abuse as well. The Supreme Court ruled in 1953 that the text does not violate the principle of non-discrimination enshrined in the Constitution. ${ }^{85}$ There are no clauses regarding marital rape, and rape without injury is among the offences that cannot be prosecuted without a complaint by the victim. In that respect, the CEDAW Committee, in its concluding observations, noted that the Ministry of Justice established a committee to review the penal code, and this is a positive step towards the recognition of women's rights. However, the Committee required the State to address violence against women in the penal code, including domestic violence and incest, as a specific crime; to expedite the amendment of the penal code to expand the definition of rape and ensure ex officio prosecution of sex crimes; to amend the penal code to explicitly criminalise marital rape; to expedite the judicial process for issuing emergency protection order; to encourage the victims of all forms of violence to report to the authorities; to endure that the personnel is sufficiently trained to deal with cases of violence against women and girls; and to ensure that the law on domestic violence applies to all family settings. ${ }^{86}$ Japan, which holds observer status of the Council of Europe, could ratify the Istanbul Convention on preventing and combating violence against women and domestic violence, also open to non-Member States of the Council of Europe. ${ }^{87}$ The treaty would provide a complete legal framework for, among others, the identification of the elements of the crimes, including rape, to be introduced as amendments to the Japanese penal code. Japan has ratified other conventions of the Council of Europe. We are perfectly aware of the fact that the ratification of the Istanbul Convention is a huge challenge, considering the detailed obligations States must comply with, also in terms of public expenditure and of measures to eradicate discrimination against women rooted in the society. The ratification will however effectively implement the policy

\footnotetext{
${ }^{84}$ Yano (2007, p. 190).

${ }^{85}$ Yano (2007, p. 201). Judgment of 24 June 1953, Supreme Court, Supreme Court Judicial Precedent Collection, Vol. 7 no. 6, p. 1366.

${ }^{86} \mathrm{CEDAW} / \mathrm{C} / \mathrm{JPN} / \mathrm{CO} / 7-8$, para. 23.

${ }^{87}$ Article 76 of the Convention.
} 
adopted by the Japanese government in 2013, 'Toward a society in which all women shine. ${ }^{88}$

Let us now turn to trafficking in persons, especially women. Japan is one of the largest receiving countries of trafficking in women. ${ }^{89}$ The country has only recently ratified the UN Palermo Convention and the UN Protocol against trafficking. ${ }^{90}$ Before legal obligations derived from the UN legal instruments, Japan started in 2005 a revision of its criminal and immigration laws. Among the most significant improvements to the law, Article 226 of the Japanese Criminal Law was amended in order to prohibit acts of abduction and kidnapping for the purpose of transportation outside the country a person is located. In other words, the provision is applicable to all victims of human trafficking regardless of their nationality or location. ${ }^{91}$ Japan also adopted an Action plan to combat trafficking in persons in December 2014, and established the Council for the promotion of measures to combat trafficking in persons. ${ }^{92}$ In the Asian region, Japan and ASEAN adopted a common action plan in 2003, where there is a clear commitment to 'intensify efforts to combat people smuggling and trafficking in persons by enhancing their focus on tackling the root causes of such crimes and developing more effective information sharing arrangements,' and to 'promote cooperation among coast guards and competent authorities, through, among other, measures conducting training exercises in combating piracy and preventing and curbing transnational organised crimes such as illicit drug and human trafficking. ${ }^{, 93}$ Despite the efforts undertaken by the State, the CEDAW Committee observed that 'State party remains a source, transit and destination country for trafficking in persons, in particular women and girls, for purposes of labour and sexual exploitation,' in particular for sexual exploitation in the entertainment industry. ${ }^{94}$ The Committee recommended that the State party intensify inspections and monitoring programmes, and 'continue efforts aimed at bilateral, regional and international cooperation to prevent trafficking, including by exchanging information with other countries in the region and harmonizing legal procedures to prosecute traffickers. ${ }^{95}$ An enormous step forward would be the ratification by Japan of the ASEAN Convention against trafficking, which would allow closer cooperation with the countries in the region to combat this crime.

\footnotetext{
${ }^{88} \mathrm{http} / / /$ www.mofa.go.jp/fp/pc/page23e_000181.html (last accessed on 1 June 2017).

${ }^{89}$ Kamino (2007, p. 83).

${ }^{90}$ Japan ratified the Convention and the Protocol on 11 July 2017.

${ }^{91}$ Kamino (2007, p. 88).

${ }^{92} \mathrm{CEDAW} / \mathrm{C} / \mathrm{JPN} / \mathrm{CO} / 7-8$, para. 26.

${ }^{93}$ The ASEAN-Japan action plan, 2013, letter C), paras. 8 and 12. http://asean.org/the-asean-japanplan-of-action-3/(last accessed on 1 June 2017).

${ }^{94} \mathrm{CEDAW} / \mathrm{C} / \mathrm{JPN} / \mathrm{CO} / 7-8$, para. 26.

${ }^{95} \mathrm{CEDAW} / \mathrm{C} / \mathrm{JPN} / \mathrm{CO} / 7-8$, para. 27.
} 


\section{Regionalisation and Dialogue Between Legal Systems: Some Conclusions}

Discrimination against women, which, as defined by the CEDAW, consists in 'any distinction, exclusion or restriction made on the basis of sex' that impairs the recognition, enjoyment or exercise by women of human rights (Article 1), is still persistent in every country in the world. In recent years, in particular, countering violence against women, as a form of discrimination against women, has become high priority at the international level and it is present in all political agendas. The nature of discrimination can differ from country to country. As we have mentioned, in some countries discrimination is still provided by the law, in others the law does not openly discriminate against women, but gender equality has never been completely achieved. Historically, feminists tried to obtain first de jure equality demanding the right to vote, since that was the first level in the recognition that women and men must enjoy equal rights. ${ }^{96}$

In the majority of European and Asian countries, where laws on equality have been adopted, the core of the problem is de facto discrimination. As outlined by the UN Committee on economic social and cultural rights, 'substantive equality for men and women will not be achieved simply through the enactment of laws or the adoption of policies that are gender-neutral on their face,' because 'they do not take account of existing economic, social and cultural inequalities, particularly those experienced by women. ${ }^{97}$ Most countries in the world fail to address 'structural' discrimination, and the data that we have provided on the gender pay gap and on violence against women demonstrate this trend.

As a consequence, the legal instruments that have been adopted over the years both at the international and regional level must be considered as important steps forward in responding to both de jure and de facto discrimination. In the previous pages we analysed the main regional legal instruments in force to promote women's rights, focusing in particular on the two most recent ones, the Council of Europe Istanbul Convention regarding violence against women and domestic violence, and the ASEAN Convention against trafficking in persons, especially women and children. Both conventions must be welcomed, despite some weaknesses that we have briefly explained, since they pursue gender equality by countering criminal acts committed against women because they are women.

\footnotetext{
${ }^{96}$ Just to mention two examples. In 1792, Mary Wollstonecraft wrote A Vindication of the Rights of Woman, where she examined natural rights and stated that since these rights are bestowed by God they should be enjoyed by both men and women. In Japan, Fusae lchikawa dedicated her whole life to women's involvement in politics. In 1890, Japanese women were legally prohibited from engaging in political activities. Ichikawa emerged as a leader of the Women's Suffrage League, and played a pivotal role in obtaining women's suffrage.

${ }^{97}$ Committee on economic social and cultural rights, General Comment No. 16 on Article 3 of the Covenant on economic, social and cultural rights, E/C. 12/2005/3 13 May 2005, para. 6.
} 
Since gender inequality and discrimination against women are a recurrent pattern in the world, we argue first that regionalisation of the protection of women's rights is positive since it reflects the major challenges of a given society. The prohibition of female genital mutilation, just to show an example, does make sense in societies where girls are forced to undergo this practice, not in others. Regionalisation is also an instrument to avoid too general provisions of law which are not capable of being sufficiently effective.

Secondly, we contend that the dialogue between legal systems could be fruitful in order to ameliorate the mechanisms in force to promote women's rights. The fact that the ASEAN Convention against trafficking reproduces in its preamble a recital taken by the Council of Europe Convention against trafficking, and that the ACWC has started a monitoring mechanism to assess the correct implementation of the Convention are illustrative examples in that respect. Dialogue does not mean imposition of models, but it implies taking the best practices from each experience and make them their own. Therefore, the ratification by the European Union of the Council of Europe Istanbul Convention would be a major achievement in order to provide a coherent framework for the actions in favour of women. ${ }^{98}$ The EU ratification would also provide encouragement to its Member States, as well as non-Member States of the Council of Europe, such as Japan, to ratify the Convention. ${ }^{99}$ Furthermore, the Istanbul Convention could constitute a model for a future regional ASEAN Convention on women's rights, having as its scope the transformation of non-binding provisions included in the action plan adopted within the ASEAN system into mandatory rules, whose respect would be subject to a monitoring system. The proposal is not far-fetched. In the relations among the European Union and ASEAN, human rights are at the centre of the cooperation. In the joint communication to the European Parliament and the ASEAN of 2015, the EU committed to support the ASEAN human rights mechanism, to host visits of the ACWC, and 'to step dialogue and cooperation with ASEAN on issues such as the rights of migrants and victims of trafficking, business and human rights/corporate social responsibility, torture, women's and children's rights, gender equality and the fight against discriminations. ${ }^{100}$ With regard to Japan, we are convinced that the ratification by the country of the Council of Europe Istanbul Convention and the ASEAN Convention against trafficking would enhance the protection of women's rights on a national level and spur the needed reforms that the State has gradually undertaken over the years.

\footnotetext{
${ }^{98}$ The process has already started. The EU signed the Convention on 13 June 2017.

${ }^{99}$ On the impact of ratification by the EU of the Istanbul Convention, see De Vido (2017).

${ }^{100}$ Joint Communication to the European Parliament and the Council. The EU and ASEAN: A Partnership with a Strategic Purpose, 18 May 2015, JOIN (2015) 22 final, p. 13.
} 


\section{References}

Asakura M (2005) Gender and diversification of labour forms in Japan. In: Conaghan J, Rittich K (eds) Labour law, work, and family. Oxford University Press, Oxford, pp 177-194

Asis MMB (2008) Human trafficking in East and South-East Asia: searching for structural factors. In: Cameron S, Newman E (eds) Trafficking in humans: structural factors. United Nations University, Tokyo, pp 181-205

Bond JE (2003) International intersectionality. A theoretical and pragmatic exploration of women's international human rights violations. Emory Law Journal 52:71-186

Charlesworth H (2009) Inside/outside: women and the international human rights system. In: Constantinides A, Zaikos N (eds) The diversity of international law. Martinus Nijhoff Publishers, Leiden-Boston, pp 381-398

Chinkin C (2012a) Feminism, approach to international law. In: Wolfrum R (ed) The Max Planck Encyclopedia of public international law, vol IV. Oxford University Press, Oxford, pp 1-7

Chinkin C (2012b) Women, rights of, international protection. In: Wolfrum R (ed) The Max Planck encyclopedia of public international law, vol X. Oxford University Press, Oxford, pp 891-900

Chinkin C, Charlesworth H (2000) The boundaries of international law. Manchester University Press, Manchester

Cook R, Cusack S (2010) Gender stereotyping transnational legal perspectives. University of Pennsylvania Press, Philadelphia

De Vido S (2016a) Donne, violenza e diritto internazionale. Mimesis, Milano

De Vido S (2016b) The Council of Europe Istanbul Convention on preventing and combating violence against women and domestic violence: an appraisal. In: De Vido S, Candiotto L (eds) Home-made violence. Mimesis, Milano, pp 75-87

De Vido S (2016c) Women's human rights in Japan: two recent national judgments under the lens of international law. Federalismi.it 2:1-12

De Vido S (2017) The ratification of the Council of Europe Istanbul Convention by the EU: a step forward in the protection of women from violence in the European Legal System. Eur J Legal Stud 9(2):69-102

Gallagher AT, Holmes P (2008) Developing an effective criminal response to human trafficking: lessons from the front line. Int Crim Justice Rev 18:318-343

Gallagher AT (2001) UN protocols on trafficking and migrant smuggling. Hum Rights Q 23:9751004

Gallagher AT (2010) The international law on human trafficking. Cambridge University Press, Cambridge

Hervey T (2005) Thirty years of EU sex equality law: leading backwords, looking forwards. Maastricht J Eur Comp Law 12:307-325

Kamino T (2007) Japanese law and policy against human trafficking. In: Tsujimura M, Yano E (eds) Gender \& law in Japan. Tohoku University Press, Sendai, pp 79-98

Nakashima K (2007) Japanese implementation of international gender equality law: monitoring the CEDAW. In: Tsujimura M, Yano E (eds) Gender \& law in Japan. Tohoku University Press, Sendai, pp 31-55

Nussbaum MC (2006) Frontiers of Justice. Belknap Press, Cambridge

Orford A (2002) Feminism, imperialism and the mission of international law. Nordic J Int Law 71:275-296

Otto D (2013) Women's Rights. In: Moeckli D, Shah S, Sivakumaran S (eds) International human rights law. Oxford University Press, Oxford, pp 316-335

Pati R (2009) Beyond the duty to protect: expanding accountability and responsibilities of the State in combating human trafficking. In: Constantinides A, Zaikos N (eds) The diversity of international law. Martinus Nijhoff Publishers, Leiden-Boston, pp 319-341 
Shelley L (2011) Human trafficking: why is it such an important women's issue? In: Bergoffen D, Gilbert PR, Harvey T, McNeely CL (eds) Confronting global gender justice. Women's lives human rights. Routledge, Abington, pp 35-49

Stoll PT (2012) Human rights, treaty bodies. In: Wolfrum R (ed) The Max Planck Encyclopedia of public international law. Oxford University Press, Oxford, pp 5-14

Sümer S (2009) European gender regimes and policies. Ashgate, London

Tsujimura M (2007) Law and Praxis for a gender-equal society. In: Tsujimura M, Yano E (eds) Gender \& law in Japan. Tohoku University Press, Sendai, pp 7-30

Tsujimura M (2010) Introduction. In: Tsujimura M (ed) Gender equality in multicultural societies. Gender, diversity, and conviviality in the age of globalization. Tohoku University Press, Sendai

Yano E (2007) Violence against women in Japan: contemporary challenges. In: Tsujimura M, Yano E (eds) Gender \& Law in Japan. Tohoku University Press, Sendai, pp 189-216

\section{Author Biography}

Sara De Vido is assistant professor of International Law at Ca' Foscari University in Venice, Italy, where she teaches international law and European law. She is one of the professors at the Venice International University, San Servolo, Venice. She is vice-director of the Centre for Human Rights (Cestudir) at Ca' Foscari. She is affiliate to the Manchester International Law Centre, where she co-founded the Women in international law network (Wilnet). She has spent several research periods abroad, including at The University of Manchester in Autumn 2015, at the University of Kobe, Japan, and Hitotsubashi (Tokyo, Japan) in 2014 and 2016-beginning of 2017. She teaches in Italian, English and French both in Italy and abroad. Her main interests of research are: the fight against transnational criminality and women's rights under international law. Among her publications, a monograph on the Council of Europe Istanbul Convention on preventing and combating violence against women and domestic violence (Donne, violenza e diritto internazionale, Mimesis, 2016), which she presented at the Council of Europe office of Venice in May 2017. She was invited by the Council of Europe as expert to a conference in Pristina, Kosovo, in June 2017, to talk to the local authorities about the Istanbul Convention.

Open Access This chapter is licensed under the terms of the Creative Commons Attribution-NonCommercial-NoDerivatives 4.0 International License (http://creativecommons. org/licenses/by-nc-nd/4.0/), which permits any noncommercial use, sharing, distribution and reproduction in any medium or format, as long as you give appropriate credit to the original author (s) and the source, provide a link to the Creative Commons license and indicate if you modified the licensed material. You do not have permission under this license to share adapted material derived from this chapter or parts of it.

The images or other third party material in this chapter are included in the chapter's Creative Commons license, unless indicated otherwise in a credit line to the material. If material is not included in the chapter's Creative Commons license and your intended use is not permitted by statutory regulation or exceeds the permitted use, you will need to obtain permission directly from the copyright holder. 